\title{
Positron Emission Tomography Techniques to Measure Active Inflammation, Fibrosis and Angiogenesis: Potential for Non-invasive Imaging of Hypertensive Heart Failure
}

\author{
Viktoria Balogh ${ }^{1,2}$, Mark G. MacAskill ${ }^{1,2}$, Patrick W. F. Hadoke ${ }^{1}$, Gillian A. Gray ${ }^{1}$ and \\ Adriana A. S. Tavares ${ }^{1,2 *}$ \\ ${ }^{1}$ Centre for Cardiovascular Science, The Queen's Medical Research Institute, The University of Edinburgh, Edinburgh, \\ United Kingdom, ${ }^{2}$ Edinburgh Imaging, The Queen's Medical Research Institute, The University of Edinburgh, Edinburgh, \\ United Kingdom
}

OPEN ACCESS

Edited by:

Xiaowei Wang,

Baker Heart and Diabetes

Institute, Australia

Reviewed by:

James Thackeray,

Hannover Medical School, Germany

Masao Miyagawa,

Ehime University Hospital, Japan

*Correspondence:

Adriana A. S. Tavares

adriana.tavares@ed.ac.uk

Specialty section:

This article was submitted to

Cardiovascular Imaging

a section of the journal

Frontiers in Cardiovascular Medicine

Received: 01 June 2021

Accepted: 22 July 2021

Published: 17 August 2021

Citation:

Balogh V, MacAskill MG

Hadoke PWF, Gray GA and Tavares AAS (2021) Positron Emission

Tomography Techniques to Measure

Active Inflammation, Fibrosis and

Angiogenesis: Potential for

Non-invasive Imaging of Hypertensive

Heart Failure.

Front. Cardiovasc. Med. 8:719031.

doi: 10.3389/fcvm.2021.719031
Heart failure, which is responsible for a high number of deaths worldwide, can develop due to chronic hypertension. Heart failure can involve and progress through several different pathways, including: fibrosis, inflammation, and angiogenesis. Early and specific detection of changes in the myocardium during the transition to heart failure can be made via the use of molecular imaging techniques, including positron emission tomography (PET). Traditional cardiovascular PET techniques, such as myocardial perfusion imaging and sympathetic innervation imaging, have been established at the clinical level but are often lacking in pathway and target specificity that is important for assessment of heart failure. Therefore, there is a need to identify new PET imaging markers of inflammation, fibrosis and angiogenesis that could aid diagnosis, staging and treatment of hypertensive heart failure. This review will provide an overview of key mechanisms underlying hypertensive heart failure and will present the latest developments in PET probes for detection of cardiovascular inflammation, fibrosis and angiogenesis. Currently, selective PET probes for detection of angiogenesis remain elusive but promising PET probes for specific targeting of inflammation and fibrosis are rapidly progressing into clinical use.

Keywords: PET imaging, hypertensive heart failure, fibrosis, inflammation, angiogenesis

\section{INTRODUCTION}

Heart failure is one of the leading causes of death worldwide with $\sim 35 \%$ risk of death within the first year after diagnosis (1-3). It is a chronic, debilitating condition which affected around 40 million people globally in 2015 (4). The prevalence of heart failure greatly increases with age and has also increased over the past decades $(5,6)$. Chronic hypertension has been identified as a cause of heart failure, and is associated with a 2 -fold increase in the risk of heart failure in men, and a 3 -fold increase in women, compared to those within the healthy range of blood pressure. In addition, lifetime risk of heart failure can double with an increase in blood pressure from under 
$140 / 90 \mathrm{mmHg}$ to over $160 / 100 \mathrm{mmHg}$ (7). Angiotensin II, which has an important role in the development of hypertension and associated cardiovascular and hypertensive heart disease (8-11), influences a number of signaling pathways implicated in the pathogenesis of heart failure (Figure 1). Angiotensin-II-induced inflammation and fibrosis in the myocardium, due to increased pressure overload, contributes to the development of heart failure (11). It has also been suggested that angiotensin II treatment in mice can give rise to fibroblast populations in the heart which are unrelated to myofibroblasts (16).

Imaging techniques can help assess the function and morphology of the myocardium, both in the healthy heart and during the development and progression of heart failure. Several imaging modalities are available in the clinical setting, including ultrasound, computerized tomography (CT), magnetic resonance imaging (MRI), and molecular imaging techniques [single photon emission computed tomography (SPECT), and positron emission tomography (PET)] (17). PET imaging provides quantitative information on biological processes in the living body by quantifying the distribution and uptake of a radiotracer. This technique has high sensitivity for detection of molecular changes and is uniquely placed to investigate disease activity in vivo in the context of heart failure. The use of radiotracers allows for high signal specificity by exclusively targeting distinct cellular processes at the molecular level, thus allowing for the detection of changes at early time points during pathology (18).

The most established cardiovascular PET radiotracers target myocardial perfusion and viability; however, there is a wide range of pathways and processes which can be imaged using these radiotracers, either pre-clinically or in the clinic. Table 1 summarizes the properties of key radiotracers used in classical cardiac PET imaging, with examples and further details of radiotracers targeting perfusion, metabolism, viability, cell death innervation. Table 2 lists current and emerging radiotracers used for imaging angiogenesis, extracellular matrix (ECM) remodeling and inflammation.

A critically important clinical question is how we can assess the extent of molecular changes, such as fibrosis, inflammation and angiogenesis, in the heart during development and progression of heart failure. Targeting markers of active disease would provide a more accurate representation of each individual's condition, enabling delivery of more personalized medical care. This specific-targeting PET approach could help differentiate those in urgent need of interventions, e.g., with ongoing active or early stage fibrosis, from those who had an older injury that have established non-active tissue scars. Importantly, cardiac molecular imaging for heart failure diagnosis would be beneficial for determining prognosis and adequate interventions and treatments $(54,55)$. Despite the well-established treatments and interventions available for hypertension, a significant majority of those who have the condition do not have it under control, according to a US based assessment, only $43.5 \%$ of those who have hypertension have it under control. Even though, this shows great improvement since the 2000s, the overall burden of hypertension increased consistently by over 21 million by 2016 despite a 3\% decrease in prevalence (56). There is also opportunity for investigating whether the damage done to the myocardium prior to patients being diagnosed could be reversed. PET radiotracers could be used to assess pharmacological interventions.

The variety of pathways and radiotracers included in this review indicates that PET radiotracers explored for one type of pathology have the potential to become valuable tools in other conditions where the same pathways are involved. This review will discuss established and emerging PET techniques that may be useful in assessing conditions such as hypertensive heart failure.

\section{CLASSIC PET IMAGING TECHNIQUES FOR ASSESSMENT OF BASIC CARDIAC PHYSIOLOGY AND PATHOPHYSIOLOGY}

\section{Perfusion, Metabolism and Viability}

In the clinic, the main application of imaging with radiotracers in heart failure is the assessment of myocardial perfusion to determine viability and potential ischemia, often via SPECT imaging (57). PET perfusion radiotracers previously used for cardiovascular imaging of perfusion include ${ }^{82} \mathrm{Rb},{ }^{13} \mathrm{~N}_{-} \mathrm{NH}_{3}$, ${ }^{13} \mathrm{O}-\mathrm{H}_{2} \mathrm{O}$ and ${ }^{18} \mathrm{~F}$-Fluripiridaz (Table $\left.\mathbf{1}\right)(23,58,59)$. In addition to perfusion measurements, most cardiovascular PET imaging studies focus on assessing myocardial metabolism and viability using ${ }^{18} \mathrm{~F}-\mathrm{FDG}$, a marker of glucose metabolism that has over $90 \%$ accuracy for prediction of future recovery of myocardial function $(60,61)$. However, because ${ }^{18} \mathrm{~F}-\mathrm{FDG}$ is a glucose analog, it is also taken up from the circulation by cells (e.g., macrophages) which are metabolically active as a result of active inflammation (62); thereby confounding assessment of myocardial viability. Unsurprisingly, due to its association with inflammatory cells, ${ }^{18} \mathrm{~F}-\mathrm{FDG}$ has been used to investigate myocardial and coronary inflammation in several diseases, including myocardial infarction and sarcoidosis (63-65). Although widely disseminated in the clinical arena, the lack of specificity associated with ${ }^{18}$ F-FDG can make it difficult to distinguish between myocardial viability and tissue inflammation. Furthermore, ${ }^{18}$ F-FDG has high uptake in healthy myocardium that can mask areas with lower uptake, skewing the results of image analysis (66).

\section{Cell Death}

Cardiac remodeling as a component of heart failure has been associated with increased rates of cell death in the myocardium, with the activation of related signaling pathways due to ischemia and pressure overload $(67,68)$. Radiotracers for investigating cell death include ${ }^{18} \mathrm{~F}$-ML-8 $\left[{ }^{18} \mathrm{~F}\right.$-labeled 2 -(3-fluoropropyl)2-methyl-malonic acid $]$ and ${ }^{18} \mathrm{~F}$-ML-10 $\quad\left[{ }^{18} \mathrm{~F}\right.$-labeled 2 -(5fluoropentyl)-2-methyl-malonic acid] (Table 1) (34). These small molecule compounds are part of the ApoSense family, and they recognize the membrane phospholipid scrambling of apoptotic cells where they then accumulate (69). These have been applied in the setting of myocardial infarction (permanent left coronary artery ligation) in rats to investigate apoptosis in the forming scar and thus disease progression (34). In this study, both ${ }^{18} \mathrm{~F}$-ML-8 and ${ }^{18} \mathrm{~F}-\mathrm{ML}-10$ were used in combination 


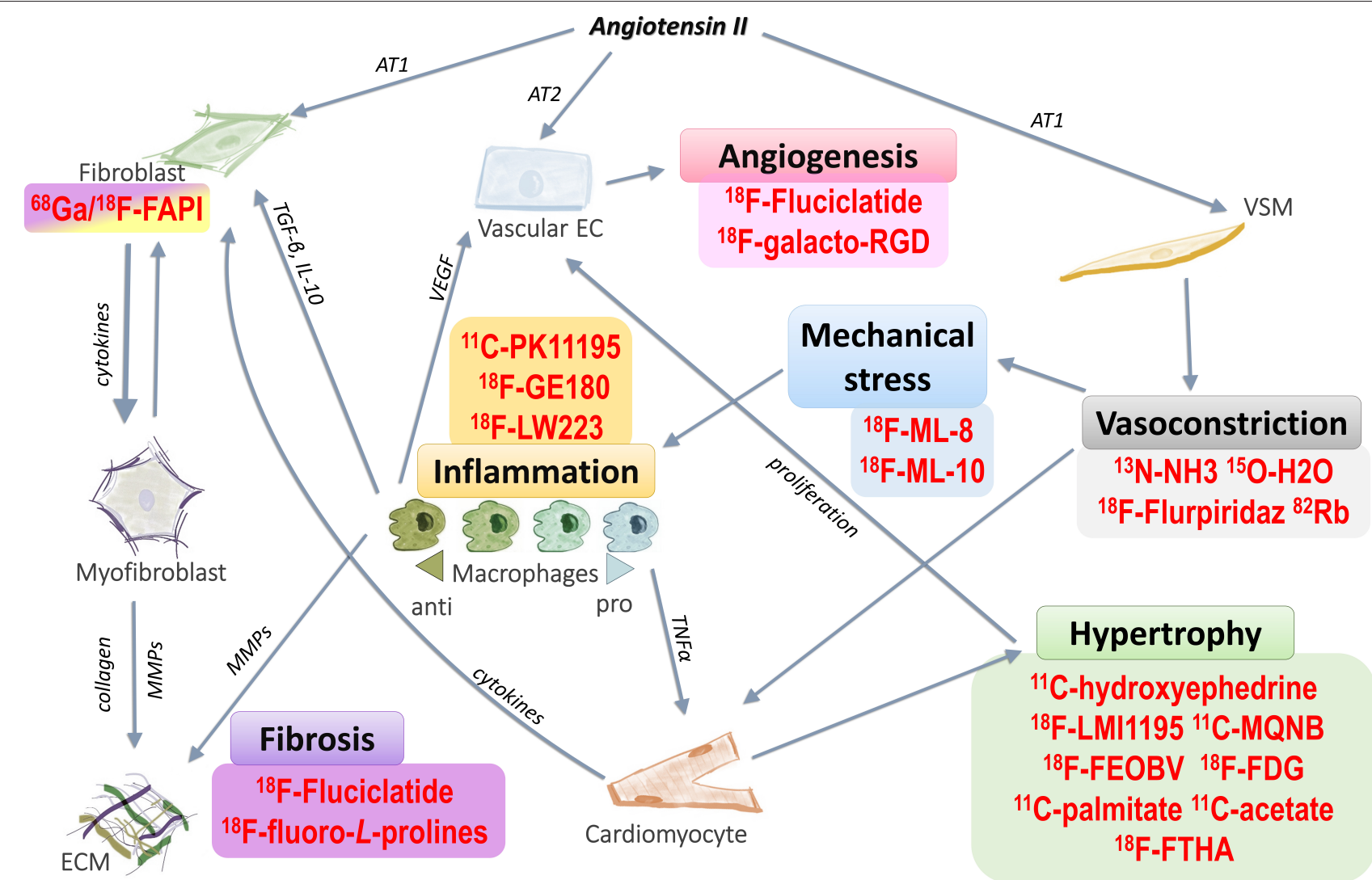

FIGURE 1 | Targeting pathways related to hypertensive heart failure with PET radiotracers. Angiotensin II stimulates a number of different pathways that contribute to cardiac remodeling in hypertensive heart failure. These pathways can be targeted with various PET radiotracers, which can then assess processes related to, but not limited to, hypertrophy, vasoconstriction, mechanical stress, inflammation, fibrosis and angiogenesis. Examples of these radiotracers are shown above. Angiotensin II acting through the AT1 receptor on vascular smooth muscle it can induce vasoconstriction, leading to mechanical stress on the cardiovascular system. As a result, cardiomyocytes enlarge and the heart hypertrophies. Hypertrophy leads to inadequate blood supply to the affected areas in the heart, inducing the proliferation of vascular endothelial cells to form new blood vessels (angiogenesis), and this is enhanced by proangiogenic signals from anti-inflammatory macrophages. Mechanical stress also causes inflammation in the myocardium, enhancing various pro- and anti-inflammatory signaling pathways, which can lead to cardiac remodeling by promoting fibrosis. Angiotensin II also increases proliferation of fibroblasts via the $\mathrm{AT}_{1}$ receptor. In contrast, it decreases proliferation of vascular endothelium through activation of the $\mathrm{AT}_{2}$ receptor. Fibroblasts (as well as macrophages and vascular endothelial cells) may directly differentiate into myofibroblasts. The main activity of myofibroblasts is the generation of collagen deposits in the ECM (12-15) AT , angiotensin receptor type 1; $A T_{2}$, angiotensin receptor type 2; VEGF, vascular endothelial growth factor; TGF- $\beta$, transforming growth factor beta; IL-10, interleukin 10; TNF- $\alpha$, tumor necrosis factor alpha; MMPs, matrix metalloproteinases; ECM, extracellular matrix. List of PET radiotracers and their application are presented in more detail in Tables 1, 2.

with cardiac ultrasound and PET imaging with ${ }^{18} \mathrm{~F}-\mathrm{FDG}$ to visualize metabolically-active myocardium. The PET signal of both radiotracers targeting apoptosis was high in the areas where ${ }^{18}$ F-FDG showed no uptake, suggesting the cells labeled did not have active metabolism which is indicative of infarct regions (34).

\section{Cardiac Innervation}

Changes in signals from the autonomic nervous system can affect progression of heart failure, with an associated increase in sympathetic drive shown to be worsening the condition, whereas parasympathetic activity has been suggested to be cardioprotective $(70,71)$. The integrity of both can be investigated with PET radiotracers. ${ }^{11} \mathrm{C}$-hydroxyephedrine $[(N$ methyl- ${ }^{11} \mathrm{C}$ )-metahydroxyephedrine or $\left.{ }^{11} \mathrm{C}-m \mathrm{HED}\right]$ is the most commonly used PET radiotracer for imaging cardiac sympathetic innervation (Table 1). It has been used to visualize sympathetic nerves in the heart, focusing on the reuptake of norepinephrine at nerve terminals, and this could be a useful way to investigate the increased sympathetic drive in heart failure (72). Another radiotracer that targets sympathetic innervation is ${ }^{18} \mathrm{~F}$-LMI1195 $\{\mathrm{N}$-[3-bromo-4-(3-18F-fluoro-propoxy)-benzyl]-guanidine\}, which provides an option with a longer half-life compared to ${ }^{11} \mathrm{C}-m \mathrm{HED}$, while investigating the same area of physiology. It targets the noradrenaline transporter, and in a rabbit model of regional cardiac sympathetic denervation, it successfully mapped sympathetic denervation in the myocardium (73). It should be noted, however, that this radiotracer when used in a mouse model of myocardial infarction was not successful at mapping presynaptic norepinephrine transporters, important 
TABLE 1 | Classic PET radiotracers for cardiac imaging applications.

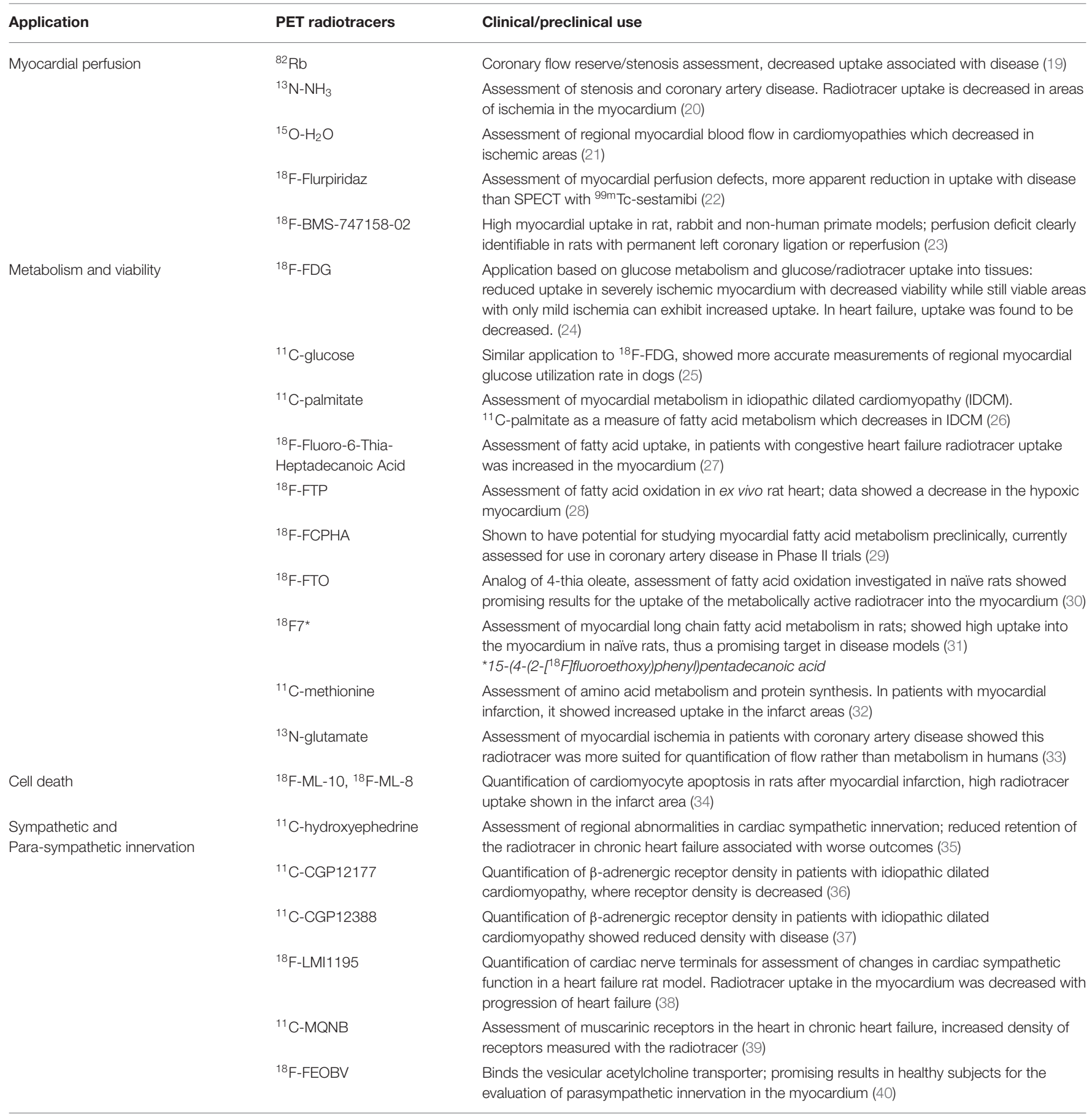

for assessing sympathetic function, as opposed to imaging with ${ }^{11} \mathrm{C}-m \mathrm{HED}$ (74). Radiotracers for imaging the parasympathetic system with $\mathrm{PET}$ include ${ }^{11} \mathrm{C}$-methylquinuclidinyl benzilate $\left({ }^{11} \mathrm{C}-\mathrm{MQNB}\right)$ and ${ }^{18} \mathrm{~F}$-fluoroethoxybenzovesamicol $\left({ }^{18} \mathrm{~F}-\right.$ FEOBV); although this type of imaging is associated with physiological limitations due to the myocardium having a low density of cholinergic neurons $(75,76)$. ${ }^{11} \mathrm{C}-\mathrm{MQNB}$, a muscarinic antagonist, was used to target and investigate active muscarinic acetylcholine receptors in the heart and suggested that the highest accumulation of these receptors was in the ventricular septum. It was also suggested that a conformational change of the muscarinic receptor could increase the affinity for the radiotracer, thus the physiologically active receptors were able to bind the radiotracer more readily (75). The radiotracer ${ }^{18} \mathrm{~F}-\mathrm{FEOBV}$ binds to the vesicular acetylcholine transporter of cholinergic neurons and the reduction of this transporter can 
TABLE 2 | Current and emerging PET radiotracers for cardiac imaging of angiogenesis, extracellular matrix remodeling, the renin-angiotensin system and myocardial inflammation.

\begin{tabular}{|c|c|c|}
\hline Application & PET radiotracers & Clinical/preclinical use \\
\hline \multirow[t]{3}{*}{ Angiogenesis } & ${ }^{18}$ F-Fluciclatide & $\begin{array}{l}\alpha_{v} \beta_{3} \text { integrin-selective radiotracer to investigate myocardial repair following infarction, uptake } \\
\text { was increased in infarcted regions with better repair, and predicted areas of recovery in patients } \\
\text { (41) }\end{array}$ \\
\hline & $\begin{array}{l}{ }^{18} \mathrm{~F} \text {-galacto-RGD, } \\
{ }^{68} \mathrm{Ga}-\mathrm{NODAGA}-\mathrm{RGD} \\
{ }^{68} \mathrm{Ga}-\mathrm{TRAP}(\mathrm{RGD})_{3}\end{array}$ & $\begin{array}{l}\text { All used for } \alpha_{v} \beta_{3} \text { integrin imaging, to monitor angiogenic repair mechanisms after myocardial } \\
\text { infarction in rats. Uptake of }{ }^{68} \mathrm{Ga} \text {-labeled radiotracers was comparably increased to } \\
{ }^{18} \mathrm{~F} \text {-galacto-RGD in the infarct area (42) }\end{array}$ \\
\hline & ${ }^{64} \mathrm{Cu}-\mathrm{NOTA}$-TRC105 & $\begin{array}{l}\text { Assessment of newly formed blood vessels in a myocardial infarction rat model to investigate } \\
\text { ischemia-induced angiogenesis, with increased uptake in the infarct zone at earlier time-points } \\
\text { (43) }\end{array}$ \\
\hline \multirow[t]{3}{*}{ ECM remodeling } & ${ }^{68} \mathrm{Ga}-\mathrm{FAPI}-04$ & $\begin{array}{l}\text { Assessment of fibroblast activity after myocardial infarction in rats with a radiolabeled fibroblast } \\
\text { activation protein inhibitor. Uptake increased in the border areas of the infarcted myocardium } \\
\text { (44) }\end{array}$ \\
\hline & ${ }^{18} \mathrm{~F}-\mathrm{FXXII}$ & $\begin{array}{l}\text { Assessment of extracellular matrix crosslinking after myocardial infarction in mice. Radiotracer } \\
\text { uptake was increased in the heart after infarction (45) }\end{array}$ \\
\hline & ${ }^{18} \mathrm{~F}$-fluoro- $L$-prolines & $\begin{array}{l}\text { Assessment of myocardial fibrosis in a myocardial infarct rat model. Uptake was increased in } \\
\text { the infarct area with trans and in the remote myocardium with cis isomer (46) }\end{array}$ \\
\hline $\begin{array}{l}\text { Renin-angiotensin } \\
\text { system }\end{array}$ & ${ }^{11} \mathrm{C}-\mathrm{KR} 3117$ & $\begin{array}{l}\text { Targets the angiotensin receptor type 1, was shown to have increased uptake in the infarct } \\
\text { area in pigs after myocardial infarction compared to the remote areas. Also shown to be safe to } \\
\text { use in humans (47) }\end{array}$ \\
\hline \multirow[t]{6}{*}{$\begin{array}{l}\text { Myocardial } \\
\text { inflammation }\end{array}$} & ${ }^{18} \mathrm{~F}-\mathrm{FDG}$ & $\begin{array}{l}\text { Assessment of inflammation in myocardial infarction. Uptake is associated with the increase in } \\
\text { macrophages around infarct region, but signal can be obscured by the radiotracer's metabolic } \\
\text { properties (48) }\end{array}$ \\
\hline & $\begin{array}{l}{ }^{18} \text { F-Fluoromethyl- } \\
\text { PBR28, } \\
{ }^{18} \text { F-CB251 }\end{array}$ & $\begin{array}{l}\text { Both bind TSPO (18 kDa translocator protein), a marker of inflammation; used in for the } \\
\text { assessment of experimental autoimmune myocarditis in rats. }{ }^{18} \mathrm{~F} \text {-CB251 showed more specific } \\
\text { uptake, corresponding to TSPO-rich areas (49) }\end{array}$ \\
\hline & ${ }^{68} \mathrm{Ga}$-pentixafor & $\begin{array}{l}\text { Targets the chemokine receptor CXCR4, increased uptake after myocardial infarction in mice } \\
\text { coinciding with upregulation of inflammatory cells. Patient-data more variable (50) }\end{array}$ \\
\hline & ${ }^{11} \mathrm{C}$-methionine & $\begin{array}{l}\text { Based on the accumulation of methionine in macrophages, uptake was most pronounced in } \\
\text { inflammatory macrophages and was increased in myocardial infarct areas at 3-day post-injury } \\
\text { in mice (51) }\end{array}$ \\
\hline & ${ }^{18}$ F-GE180 & $\begin{array}{l}\text { Targets TSPO, showed increased uptake after myocardial infarction in mice at the infarct site at } \\
\text { 1-week post-injury and in remote areas during heart failure progression } 8 \text { weeks post-injury. } \\
\text { Similar results in patients after myocardial infarction (52) }\end{array}$ \\
\hline & ${ }^{18}$ F-LW223 & $\begin{array}{l}\text { Targets TSPO, showed increased uptake in infarct areas } 7 \text { days following myocardial infarction } \\
\text { in rats, consistent with results from macrophage immunostaining (CD68, TSPO). Not } \\
\text { susceptible to the rs6971 genetic polymorphism (53) }\end{array}$ \\
\hline
\end{tabular}

initiate cardiac remodeling and heart failure (77). Experiments carried out in vitro suggested that this tracer would have limited translatability to in vivo cardiac studies due to low radiotracer retention and low density of cholinergic neurons in the heart $(75,76) .{ }^{11} \mathrm{C}$-CGP12177 PET was used to assess myocardial $\beta$-adrenergic receptor density in patients with non-ischemic cardiomyopathy to investigate left ventricular dysfunction where cardiac sympathetic regulation is affected (78). This study found that the receptor density was lower in patients and showed a significant difference in the severity of heart failure, meaning that those with severe heart failure classification had lower density of $\beta$-adrenergic receptors. Another radiotracer, $(S)-\left[{ }^{11} \mathrm{C}\right] \mathrm{CGP} 12388$, has been successful in detecting a reduction (compared with controls) in myocardial $\beta$-adrenergic receptor density in patients with idiopathic dilated cardiomyopathy (37). Therefore, assessment of sympathetic innervation with PET in heart failure can also be valuable in classifying disease severity.

\section{EMERGING PET TECHNIQUES FOR QUANTIFICATION OF PROCESSES INVOLVED IN THE PATHOGENESIS OF CARDIAC REMODELING}

\section{Renin-Angiotensin System Imaging}

Radiotracers exploring myocardial remodeling through this pathway include those targeting angiotensin II type 1 (AT1) receptors and angiotensin-converting enzyme-1 (ACE-1) (47, 79, 80). $\left[{ }^{11} \mathrm{C}\right]-\mathrm{KR} 31173$, a radiotracer targeting AT1 receptors showed an upregulation of the signal in the infarct area (compared with remote areas of the myocardium) in pigs with myocardial infarction. It was also shown to be safe to use in healthy human volunteers (47). Another AT1 antagonist radiotracer, $\left({ }^{18} \mathrm{~F}\right) \mathrm{FV} 45$, derived from valsartan had promising results when assessed for visualizing AT1 receptor distribution in rats and was shown to be selective as its uptake was successfully blocked by valsartan pre-treatment (79). A SPECT 
radiotracer, Tc-Lis (technetium-99m-labeled lisinopril/an ACE inhibitor drug) successfully detected upregulation of ACE-1 in transgenic rats which overexpress this enzyme (80). This suggests it has potential as a tool for monitoring ACE-1 upregulation in heart failure in patients.

\section{Fibrosis}

There are two main types of fibrosis in the injured heart: reactive and replacement fibrosis. Reactive fibrosis (interstitial fibrosis) happens further from the place of the injury as a response to pathological changes in the tissue elsewhere (e.g., infarct area) or as a response to changes in the physical or chemical environment (e.g., pressure overload or hypertension; myocardial inflammation). This can lead to stiffness of the ventricle wall and, thus, increased risk of heart failure. Replacement fibrosis occurs when excess collagen is deposited and fibroblasts replace the ischaemic (or necrotic) tissue at the injury site after myocardial infarct and form a scar to prevent rupturing of the wall due to the loss of the original heart muscle cells $(12,81)$.

Fibroblast activation is essential for the development of fibrosis in the heart. During cardiac remodeling, myofibroblasts produce collagen, cause interstitial fibrosis and increase collagen deposition. Cardiac remodeling, either to compensate for the loss of myocardial tissue (e.g., in myocardial infarction) or to allow the heart to adapt to the changed environment (e.g., hypertension) can lead to heart failure via development and progression of tissue fibrosis (12). Both in vitro and in vivo, the renin-angiotensin-aldosterone system, and especially angiotensin-II, have been associated with increased fibrosis and collagen synthesis (82-84). Currently, techniques available for direct imaging of cellular and molecular composition of active cardiac fibrosis are limited (12). There are also no radiotracers for imaging active fibrosis in the routine clinical setting. This type of tracer would greatly enhance diagnostics and management of patients with heart failure, although active clinical research studies are rapidly generating promising results with newly developed PET radiotracers targeting fibrosis.

Several processes during the initiation of fibrosis have been, or could be, targeted with novel and emerging PET radiotracers. These include: immune activation; leaking of the vasculature and coagulation; fibroblast recruitment and proliferation; activation of fibroblasts and myofibroblast differentiation; as well as the resulting ECM crosslinking and the accumulation of matrix components (85). Radiotracers used to investigate another aspect of tissue remodeling, fibroblast activation in cancers, are ${ }^{68} \mathrm{Ga}-$ FAPI-2 and ${ }^{68} \mathrm{Ga}-\mathrm{FAPI}-4$. The latter accumulated at the injury border after myocardial infarction in rats, making it a potential candidate for assessing fibroblast activation in the context of myocardial remodeling (Table 2) $(44,86)$.

Integrins play an important role in the adhesion of ECM components to the cellular parts of the tissue; thus radiotracers targeting integrin expression have been identified as good candidates for monitoring progression of fibrosis (87). A large group of radiotracers that were previously explored as markers of integrin expression are those targeting integrins $\alpha_{\mathrm{V}} \beta_{3}$ (Table 2). An example of an integrin radiotracer for imaging fibrosis and angiogenesis is ${ }^{18}$ F-Fluciclatide, which targets the $\alpha_{v} \beta_{3}$ integrin and was shown to have increased uptake at areas of recent injury after myocardial infarction in patients (41). Further integrin targeting radiotracers have been assessed in applications other than for myocardial imaging. Integrin $\alpha_{v} \beta_{6}$, an activator of TGF$\beta$, is upregulated during tissue injury on epithelial cells, while increased expression has been demonstrated in fibrosis (88-90).

Other more direct options for targeting the ECM components which accumulate in the myocardium during fibrosis, instead of focusing on the wider pathway processes with integrins, include imaging with radiotracers for elastin or collagen, which are more specific indicators of fibrosis (91). Imaging elastin content, as opposed to collagen, could produce a higher background signal due to the comparably higher levels of elastin in the healthy heart. In addition, elastin appears to accumulate later than collagen in the disease process, thus collagen increases could be detected earlier during remodeling. One example of an elastin radiotracer is ${ }^{18} \mathrm{~F}$-AlF-NOTA-EBM which was tested for targeting atherosclerotic plaques, but was not successful at differentiating between plaques and controls (92). To investigate infarct healing after MI and the involvement of inflammation, the tissue transglutaminases radiotracer ${ }^{18}$ F-FXIII (transglutaminase factor-XVIII) was used to visualize the infarct area and matrix crosslinking in the mouse heart (45).

Targeting collagen biosynthesis itself can also be a good strategy to quantify fibrotic activity, by observing the levels of active collagen accumulation. PET imaging can target collagen biosynthesis by the incorporation of radioactive ${ }^{18} \mathrm{~F}$-fluoroproline isomers into actively forming collagen. There are, however, four different isomers of fluoro-proline: cis- $L$, cis$D$, trans- $L$ and trans- $D$, all of which are safe to use in mice, rats, rabbits, and humans (93). The $D$ isomers are less well-characterized and less stable than the $L$ isomers, and they also possess lower affinity. Consequently, they are not optimal for studies investigating active collagen biosynthesis (94). Therefore, the $L$ isomers are the preferred probes for mapping collagen biosynthesis in vivo. Biomarkers for quantifying collagen biosynthesis in the heart via radioactive tagging of fluoroproline are particularly promising for two main reasons. Firstly, proline and hydroxyl-proline contribute almost a quarter of the amino acids in collagen (95). Secondly, proline is found almost exclusively in collagen. The use of ${ }^{18} \mathrm{~F}$-fluoro-proline radiotracers to target active fibrosis in heart failure also has a great potential to be clinically translatable for detection of active fibrosis, as they are present in the precursors of collagen. This is advantageous over other radiotracers which only visualize established fibrotic tissue through directly measuring the endproduct (e.g., ECM) of the related pathways such as collagen or elastin; or radiotracers targeting activation of fibroblasts [e.g., fibroblast activation protein (FAP) specific radiotracers] that are known to label active fibrosis and chronic reactive inflammation in the oncology setting $(96,97)$ and might be also labeling both processes in the cardiovascular context. This is because fibroblast activation occurs following proinflammatory Damage-Associated Molecular Patterns (DAMPs) released by dying cardiac cells and activated myofibroblasts produce structural extracellular matrix proteins and matricellular 
macromolecules (98). Moreover, the ability to image with both cis- and trans-fluoro-prolines is useful for determining the content of degraded or to-be-degraded immature collagen (in reactive fibrosis) and triple helix collagen (scar tissue), respectively. The cis-fluoro-proline isomer has been assessed in a rabbit lung fibrosis model, which showed promising results in the radiotracer's ability to identify fibrosis in vivo (99). Currently preclinical cardiovascular studies with ${ }^{18} \mathrm{~F}$ fluoro-prolines are underway to determine their utility in the context of myocardial infarction and hypertensive heart failure (46).

\section{Inflammation}

Inflammation and fibrosis are distinct yet interconnected processes, as unresolved inflammation causes fibrosis and fibrosis may lead to chronic inflammation; both are essential for tissue repair after injury (100). Importantly, chronic inflammation and progressive fibrosis lead to increased tissue breakdown and functional impairment of the heart (101103). Proteins and various components of the ECM influence the inflammatory cascade directly or by acting on signaling pathways triggered by localized insults and also systemic inflammation $(100,104)$. Macrophages are immune cells which can interact with fibroblasts and directly promote fibrosis and, thus, ECM deposition (105-107). In the angiotensin-II-induced hypertension model, which leads to hypertension via volume and pressure overload on the cardiovascular system, blood derived Ly6 $\mathrm{C}^{\text {high }}$ monocytes were recruited and gave rise to all cardiac macrophage populations in mice (108). Angiotensin II infusion in mice also led to proliferation of residential macrophages in the myocardium, thus during cardiac inflammatory processes, the local macrophage pool expands through both local proliferation and recruitment of blood monocytes (108). Macrophages are also involved in secreting ECM components and are especially important sources of matrix metalloproteinases (MMPs) and tissue inhibitor of metalloproteinases (TIMPs) which can be used as biomarkers of heart failure $(109,110)$. On the antiinflammatory side of the spectrum, macrophages have also been shown to degrade collagen in the ECM (111). Recently, resident cardiac anti-inflammatory macrophages were shown to be key determinants in the development of angiotensin-II mediated myocardial fibrosis (112).

PET imaging can selectively identify active inflammation by targeting important proteins expressed in inflammatory cells (113). It is therefore possible to image activated macrophages indicative of inflammation (Table 2). Inflammation after myocardial infarction can be imaged with ${ }^{18} \mathrm{~F}$-FDG and ${ }^{11} \mathrm{C}$ methionine ligands, although these radiotracers do not provide a selective or direct measurement of inflammation, as they measure glucose metabolism and cell proliferation, respectively $(51,114,115)$. It is notable, however, that uptake of ${ }^{11} \mathrm{C}$ methionine was high after myocardial infarction in the infarct area, where it showed macrophage uptake but not taken up by the impaired cardiomyocytes, indicative of inflammation in the area and thus could provide a more specific assessment than ${ }^{18} \mathrm{~F}$ FDG (51). Inflammation in atherosclerotic plaques has also been assessed with radiotracers, such as ${ }^{68} \mathrm{Ga}$-DOTATATE, targeting the somatostatin receptor. ${ }^{68} \mathrm{Ga}$-DOTATATE uptake was increased in lesions with high macrophage content (116). The radiotracer ${ }^{68} \mathrm{Ga}$-DOTANOC, which targets the somatostatin receptor, provided promising results for diagnosis of cardiac sarcoidosis in patients (117). Chemokine receptors can also be targeted in relation to inflammation. One example is CXCR4 which can be targeted by ${ }^{68} \mathrm{Ga}$-pentixafor; uptake of this tracer was increased after myocardial infarction. This uptake coincided with the infiltration of inflammatory cells but did not distinguish between uptake by pro- and anti-inflammatory macrophages (50). Another chemokine radiotracer is ${ }^{68}$ Ga-DOTA-ECL1i which targets the CCR2 (C-C chemokine receptor type 2) and was found to be localized to tissue injury sites in mouse models of cardiomyocyte ablation and myocardial infarction (118). ${ }^{64} \mathrm{Cu}$-DOTA-ECL1i was also investigated to target CCR2+ cells in heart injury mouse models, where it was comparable to the ${ }^{68} \mathrm{Ga}$-labeled probe (119). ${ }^{18} \mathrm{~F}$-FDM $\left({ }^{18} \mathrm{~F}\right.$-labeled mannose) has also been used to image inflammation of atherosclerotic plaques in rabbits, where it showed increased uptake within the aortic plaques. This tracer has potential for targeting the mannose receptors on alternatively activated macrophages within the plaques as well as in other areas (120).

The18kDa translocator protein (TSPO), which is present in the outer membrane of the mitochondria of macrophages (121, 122), has been proposed as another target for imaging cardiac inflammation. TSPO was shown to be present both in classicallyand in non-classically-activated macrophages. However, there were differences in radiotracer uptake between the types of macrophages, such as in the case of ${ }^{18} \mathrm{~F}-\mathrm{GE} 180$, which shows a binding preference for pro-inflammatory macrophages (113, $123,124)$. Understanding the underlying inflammatory and antiinflammatory mechanisms involved in cardiovascular diseases could be achieved via molecular imaging of TSPO. Therefore, TSPO is likely to be a valuable target to investigate in the setting of myocardial inflammation in heart failure. TSPO has been shown to target macrophage driven cardiac inflammation more selectively than glucose metabolism tracing (124). Although TSPO is expressed in the healthy heart, a radiotracer with high selectivity toward TSPO with concomitant low non-specific binding would enable detection of subtle changes in TSPO expression even without a zero background owing to the high sensitivity of PET for detecting changes in the $\mathrm{pM}$ to $\mathrm{nM}$ range. Notwithstanding isolation of the inflammatory cell contribution to the measured PET signal could be challenging due to the mixed substrate in hypertensive heart failure where TSPO expression might be increased in cardiomyocytes.

Previously, several ligands have been developed for targeting TSPO with PET. One of these, ${ }^{11} \mathrm{C}-\mathrm{PK} 11195$, has a low signal-tonoise ratio and high non-specific binding; whereas an alternative ligand, ${ }^{11} \mathrm{C}$-DAA1106, demonstrated superior binding to TSPO, compared with ${ }^{11} \mathrm{C}-\mathrm{PK} 11195$, when investigating microglia and inflammation in the brain (125-129). TSPO-targeted imaging with the PET radiotracer ${ }^{18} \mathrm{~F}-\mathrm{GE} 180$ also detected the increased inflammation after myocardial infarction both in mice and in humans (52). TSPO radiotracers can have a number of limitations, including: low signal-to-noise ratio; non-specific binding; and perhaps most importantly, alterations in tracer 
binding as a result of variations in the gene encoding TSPO in humans (125-130). The affinity of several radiotracers for TSPO is affected by the rs6971 human polymorphism, which means that the binding affinity of some can vary depending on which variant of the polymorphism is present. Thus a patient's genetic information would need to be assessed for full analysis of scans acquired with these ligands (130). A new selective PET radiotracer for imaging TSPO, ${ }^{18} \mathrm{~F}$-LW223, has the potential to overcome this issue. ${ }^{18} \mathrm{~F}-\mathrm{LW} 223$ has been shown to reversibly bind to its target, can be displaced by PK11195 (which indicates specificity to TSPO) while it also showed uptake consistent with macrophage infiltration after myocardial infarction in rats (53). It is potentially more readily clinically-translatable due to having similar affinity to all TSPO isoforms regardless of the presence of the previously described rs6971 human polymorphism (53, 130). Further examples of TSPO radiotracers with low sensitivity to this polymorphism are ${ }^{18} \mathrm{~F}$-FEBMP $(R)-{ }^{18} \mathrm{~F}$-NEBIFQUINIDE and $(R, S)-{ }^{18} \mathrm{~F}-\mathrm{GE} 387$ (131-133). Another TSPO radiotracer, ${ }^{18} \mathrm{~F}$-FEDAC, has been used to monitor liver fibrosis in rats, as the signal correlated well with expression of TSPO in macrophages, which was increased with disease (134). This is promising in relation to using PET to investigate inflammationinduced fibrosis and TSPO expression in macrophages in the failing heart.

\section{Angiogenesis}

Reduced blood supply to the heart tissue through impaired angiogenesis and neovascularization damages the myocardium during heart failure, and can lead to cell death due to oxidative stress and enhanced fibrotic response after cell loss (135). During hypertension, excess mechanical demand on the heart can induce hypertrophy of the myocardium leading to reduced blood supply in the newly enlarged areas resulting in hypoxia and tissue impairment and eventually heart failure. Capillary angiogenesis is important to restore function to these areas. The imbalance of capillary numbers in the heart is a consequence of myocardial enlargement, causes hypoxia in the tissue, and can lead to heart failure (136-138). Improving this capillary imbalance with pro-angiogenic mediators can improve functional outcome during heart failure. For-example neonatal rabbits undergoing aortic banding (and therefore developing pressure overload and hypertrophy) had improved angiogenesis when treated with VEGF while matrix metalloproteinase activity also increased (139). This suggests that angiogenesis and angiogenic factors can have an important role in extracellular and vascular remodeling in the myocardium. Pro-angiogenic stimuli can lead to the upregulation of growth factors, such as vascular endothelial growth factor (VEGF), which act on the vascular endothelium, promoting migration and proliferation, and, eventually, the formation of new vessels (140). Angiogenic and inflammatory pathways are also closely associated thus it can be challenging to disassociate the two processes (141).

Recently, several new PET radiotracers have been used to target angiogenesis and repair mechanisms in the myocardium (142). $\alpha v \beta 3$ integrin, a transmembrane cell surface receptor that is an important mediator of angiogenesis, and is expressed by macrophages and myofibroblasts after myocardial infarction, is also a target for imaging of angiogenesis using PET (143145). However, repair processes measured by using integrin $\alpha v \beta 3$-targeted radiotracers can be attributed to angiogenesis, fibrosis and inflammation. This is because integrin $\alpha v \beta 3$ is not a specific marker of activated endothelial cells, as it is also expressed by macrophages. Despite this limitation, it is frequently reported as a target for quantification of angiogenesis using PET radiotracers (146-149). The $\alpha \mathrm{v} \beta 3$ integrin also binds to collagen, further complicating the distinction between signals from different targets. Indeed, ${ }^{18} \mathrm{~F}$-Fluciclatide, a PET radiotracer used to image $\alpha v \beta 3$ expression, has been used to detect fibrosis in the heart after myocardial infarction (41). Other PET radiotracers used for investigating myocardial angiogenesis following infarction include: ${ }^{18} \mathrm{~F}$-galacto-RGD (clinical use), ${ }^{64} \mathrm{Cu}$-VEGF, ${ }^{18} \mathrm{~F}$-PRGD, ${ }^{64} \mathrm{Cu}$-TRC105, and multiple ${ }^{68} \mathrm{Ga}$ labeled RGD peptides (preclinical use) (Table 2) (42, 43, 148, 150-153). These radiotracers have all shown increased uptake after myocardial infarction at the infarct site. However, targeting with an RGD peptide means the potential labeling of both angiogenesis and inflammation, which can complicate clear interpretation of the results (154).

The nicotinic acetylcholine receptor $\alpha 7$ subtype $(\alpha 7 \mathrm{nAChR})$ has emerged as an alternative to integrins or VGEF receptors as a target for imaging angiogenesis. This is due to its role in the modulation of important angiogenic signaling pathways (155). Nicotine promotes angiogenesis via the nAChRs, in areas with inflammation, atherosclerosis and ischemia, as well as in areas where tumors are present $(156,157)$. An in vitro study demonstrated that, whilst endothelial cells express several isoforms of the $\mathrm{nAChR}$ receptor, the $\alpha 7 \mathrm{nAChR}$ subunit was most highly expressed. Furthermore, inhibition of angiogenesis was only obtained by selectively blocking the $\alpha 7 \mathrm{nAChR}$ subunit (157). Similarly, in vivo studies have shown that inhibiting or genetically disrupting the $\alpha 7 \mathrm{nAChRs}$ reduced angiogenesis in response to inflammatory and ischemic stimuli in both the ischemic mouse hind limb and disc angiogenesis models (157). A rat pressure overload model induced by coarctation of the abdominal aorta demonstrated increased $\alpha 7 \mathrm{nAChR}$ protein and mRNA levels in the left ventricle 16 weeks after surgery. Results from that study also showed that the animals developed cardiac hypertrophy and increased microvessel density, with expression of $\alpha 7 \mathrm{nAChR}$ most evident around the blood vessels with degeneration of cardiomyocytes also observed (155). Several radiotracers for these receptors have been used in the context of neuroimaging, the most successful being ${ }^{18} \mathrm{~F}$-ASEM, a selective $\alpha 7 \mathrm{nAChR}$ antagonist radiotracer, which is already used in clinical studies for neuropsychiatry $(158,159) .{ }^{18} \mathrm{~F}-\mathrm{NS} 14490$, a new agonist radiotracer for targeting $\alpha 7 \mathrm{nAChR}$, was first proposed as a potentially useful biomarker in cardiovascular imaging when high uptake was visualized in the brain vasculature of pigs in vivo (160).

\section{CONCLUSION}

Heart failure is an important healthcare issue of rising prevalence, with a large number of cases related to hypertension. There is 
a chronic and cumulative element of heart failure in terms of disease development and progression that could benefit from early detection to guide patient management via molecular imaging techniques, such as PET imaging. The utility of PET is particularly justified in subtle progressive hypertensive heart disease because it is the clinical imaging technique with highest sensitivity ( $\mathrm{pM}$ to $\mathrm{nM}$ range) for detection of molecular changes in vivo and non-invasively. Nonetheless, due to hypertensive heart failure having a less pronounced phenotype compared to for example myocardial infarction or oncological conditions, detection of changes could be more challenging. Currently, pre-clinical PET imaging studies with models of hypertensive heart failure are needed to test the utility of new and emerging selective PET radiotracers with clinical potential in this disease context.

\section{REFERENCES}

1. McMurray JJ, Stewart S. Epidemiology, aetiology, and prognosis of heart failure. Heart. (2000) 83:596-602. doi: 10.1136/heart.83.5.596

2. Bui AL, Horwich TB, Fonarow GC. Epidemiology and risk profile of heart failure. Nat Rev Cardiol. (2011) 8:30-41. doi: 10.1038/nrcardio.2010.165

3. National Clinical Guideline C. National Institute for Health and Clinical Excellence: Guidance. Chronic Heart Failure: National Clinical Guideline for Diagnosis and Management in Primary and Secondary Care: Partial Update. London: Royal College of Physicians (UK) Copyright (c) 2010, National Clinical Guideline Centre (2010).

4. Disease GBD, Injury I, Prevalence C. Global, regional, and national incidence, prevalence, and years lived with disability for 310 diseases and injuries, 1990-2015: a systematic analysis for the global burden of disease study 2015. Lancet. (2016) 388:1545-602. doi: 10.1016/S0140-6736(16)31678-6

5. Cowie MR. Annotated references in epidemiology. Eur J Heart Fail. (1999) 1:101-7. doi: 10.1016/S1388-9842(98)00008-7

6. McMurray JJ, Petrie MC, Murdoch DR, Davie AP. Clinical epidemiology of heart failure: public and private health burden. Eur Heart J. (1998) 19(Suppl. P):P9-16.

7. Lloyd-Jones DM, Larson MG, Leip EP, Beiser A, D'Agostino $\mathrm{RB}$, Kannel WB, et al. Lifetime risk for developing congestive heart failure: the framingham heart study. Circulation. (2002) 106:3068-72. doi: 10.1161/01.CIR.0000039105.49749.6F

8. Dostal DE, Baker KM. The cardiac renin-angiotensin system conceptual, or a regulator of cardiac function? Circ Res. (1999) 85:643-50. doi: 10.1161/01.RES.85.7.643

9. Ma TKW, Kam KKH, Yan BP, Lam YY. Renin-angiotensin-aldosterone system blockade for cardiovascular diseases: current status. Brit J Pharmacol. (2010) 160:1273-92. doi: 10.1111/j.1476-5381.2010. 00750.x

10. Raman VK, Lee YA, Lindpaintner K. The cardiac renin-angiotensinaldosterone system and hypertensive cardiac-hypertrophy. Am J Cardiol. (1995) 76:D18-23. doi: 10.1016/S0002-9149(99)80487-1

11. Gradman AH, Papademetriou V. Combined renin-angiotensin-aldosterone system inhibition in patients with chronic heart failure secondary to left ventricular systolic dysfunction. Am Heart J. (2009) 157:S1723. doi: 10.1016/j.ahj.2009.04.007

12. Frangogiannis NG. Cardiac fibrosis: cell biological mechanisms, molecular pathways and therapeutic opportunities. Mol Aspects Med. (2019) 65:7099. doi: 10.1016/j.mam.2018.07.001

13. Krenning G, Zeisberg EM, Kalluri R. The origin of fibroblasts and mechanism of cardiac fibrosis. J Cell Physiol. (2010) 225:631-7. doi: 10.1002/jcp.22322

\section{AUTHOR CONTRIBUTIONS}

VB conducted the literature search for this review article and wrote the first manuscript draft. MM, PH, GG, and AT provided comments and edits to the review paper as well as suggested additional literature for inclusion in this review article. All authors contributed to the article and approved the submitted version.

\section{FUNDING}

VB is funded by the British Heart Foundation (BHF) PhD studentship FS/17/62/33477. MM is funded by the British Heart Foundation (RG/16/10/32375). AT is funded by the British Heart Foundation (FS/19/34/34354) and is a recipient of a Wellcome Trust Technology Development Award (221295/Z/20/Z).

14. Schorb W, Booz GW, Dostal DE, Conrad KM, Chang KC, Baker KM. Angiotensin-Ii is mitogenic in neonatal rat cardiac fibroblasts. Circ Res. (1993) 72:1245-54. doi: 10.1161/01.RES.72.6.1245

15. Makita S, Nakamura M, Yoshida H, Hiramori K. Effect of angiotensinii receptor blocker on angiotensin-ii stimulated DNA-synthesis of cultured human aortic smooth-muscle cells. Life Sci. (1995) 56:Pl383-18. doi: 10.1016/0024-3205(95)98582-Z

16. McLellan MA, Skelly DA, Dona MSI, Squiers GT, Farrugia GE, Gaynor TL, et al. High-resolution transcriptomic profiling of the heart during chronic stress reveals cellular drivers of cardiac fibrosis and hypertrophy. Circulation. (2020) 142:1448-63. doi: 10.1161/CIRCULATIONAHA.119.045115

17. Paterson I, Mielniczuk LM, O’Meara E, So A, White JA. Imaging heart failure: current and future applications. Can J Cardiol. (2013) 29:31728. doi: 10.1016/j.cjca.2013.01.006

18. Shukla AK, Kumar U. Positron emission tomography: an overview. J Med Phys. (2006) 31:13-21. doi: 10.4103/0971-6203.25665

19. Gould KL, Goldstein RA, Mullani NA, Kirkeeide RL, Wong WH, Tewson TJ, et al. Noninvasive assessment of coronary stenoses by myocardial perfusion imaging during pharmacological coronary vasodilation. 8 . Clinical feasibility of positron cardiac imaging without a cyclotron using generator-produced rb-82. J Am Coll Cardiol. (1986) 7:77589. doi: 10.1016/S0735-1097(86)80336-9

20. Fathala A, Aboulkheir M, Shoukri MM, Alsergani H. Diagnostic accuracy of (13)N-ammonia myocardial perfusion imaging with PET-CT in the detection of coronary artery disease. Cardiovasc Diag Ther. (2019) 9:3542. doi: $10.21037 / \mathrm{cdt} .2018 .10 .12$

21. Frouin F, Merlet P, Bouchareb Y, Frouin V, Dubois-Rande JL, De Cesare A, et al. Validation of myocardial perfusion reserve measurements using regularized factor images of (H2O)-O-50 dynamic PET scans. J Nucl Med. (2001) 42:1737-46. Available online at: https://jnm.snmjournals.org/ content/jnumed/42/12/1737.full.pdf

22. Berman DS, Germano G, Slomka PJ. Improvement in PET myocardial perfusion image quality and quantification with flurpiridaz F 18. J Nucl Cardiol. (2012) 19:S38-45. doi: 10.1007/s12350-011-9487-4

23. Yu M, Guaraldi MT, Mistry M, Kagan M, McDonald JL, Drew K, et al. BMS747158-02: a novel PET myocardial perfusion imaging agent. J Nucl Cardiol. (2007) 14:789-98. doi: 10.1016/j.nuclcard.2007.07.008

24. Opie LH, Camici PG. Myocardial blood flow, deoxyglucose uptake, and myocyte viability in ischemia. J Nucl Med. (1992) 33:1353-6.

25. Herrero P, Sharp TL, Dence C, Haraden BM, Gropler RJ. Comparison of 1-(11)C-glucose and (18)F-FDG for quantifying myocardial glucose use with PET. J Nucl Med. (2002) 43:1530-41. Available online at: https://jnm. snmjournals.org/content/jnumed/43/11/1530.full.pdf

26. Davila-Roman VG, Vedala G, Herrero P, de las Fuentes L, Rogers JG, Kelly DP, et al. Altered myocardial fatty acid and glucose metabolism 
in idiopathic dilated cardiomyopathy. J Am Coll Cardiol. (2002) 40:2717. doi: 10.1016/S0735-1097(02)01967-8

27. Taylor M, Wallhaus TR, Degrado TR, Russell DC, Stanko P, Nickles RJ, et al. An evaluation of myocardial fatty acid and glucose uptake using PET with [18F]fluoro-6-thia-heptadecanoic acid and [18F]FDG in patients with congestive heart failure. J Nucl Med. (2001) 42:55-62. Available online at: https://jnm.snmjournals.org/content/jnumed/42/1/55.full.pdf

28. DeGrado TR, Kitapci MT, Wang S, Ying J, Lopaschuk GD. Validation of 18Ffluoro-4-thia-palmitate as a PET probe for myocardial fatty acid oxidation: effects of hypoxia and composition of exogenous fatty acids. J Nucl Med. (2006) 47:173-81. Available online at: https://jnm.snmjournals.org/content/ jnumed/47/1/173.full.pdf

29. Gheysens O, Postnov A, Nuyts J, Van Laere K, Janssens S, Cerqueira M. Quantification of myocardial perfusion in humans by PET/CT and the fatty acid analogue 18F-FCPHA: a feasibility study. J Nucl Med. (2014) 55(Suppl. 1):1770. Available online at: https://jnm.snmjournals.org/content/ 55/supplement_1/1770

30. DeGrado TR, Bhattacharyya F, Pandey MK, Belanger AP, Wang S. Synthesis and preliminary evaluation of 18-(18)F-fluoro-4-thia-oleate as a PET probe of fatty acid oxidation. J Nucl Med. (2010) 51:13107. doi: $10.2967 /$ jnumed.109.074245

31. Tu Z, Li S, Sharp TL, Herrero P, Dence CS, Gropler RJ, et al. Synthesis and evaluation of 15-(4-(2-[(1)(8)F]Fluoroethoxy)phenyl)pentadecanoic acid: a potential PET tracer for studying myocardial fatty acid metabolism. Bioconjug Chem. (2010) 21:2313-9. doi: 10.1021/ bc100343h

32. Morooka M, Kubota K, Kadowaki H, Ito K, Okazaki O, Kashida M, et al. 11C-methionine PET of acute myocardial infarction. J Nucl Med. (2009) 50:1283-7. doi: 10.2967/jnumed.108.061341

33. Krivokapich J, Barrio JR, Huang SC, Schelbert HR. Dynamic positron tomographic imaging with nitrogen-13 glutamate in patients with coronary artery disease: comparison with nitrogen-13 ammonia and fluorine18 fluorodeoxyglucose imaging. J Am Coll Cardiol. (1990) 16:115867. doi: 10.1016/0735-1097(90)90548-4

34. Ma H, Liu S, Xiong Y, Zhang Z, Sun A, Su S, et al. PET imaging of cardiomyocyte apoptosis in a rat myocardial infarction model. Apoptosis. (2018) 23:396-407. doi: 10.1007/s10495-018-1463-x

35. Pietilä $\mathrm{M}$, Malminiemi K, Ukkonen $\mathrm{H}$, Saraste $\mathrm{M}$, Någren $\mathrm{K}$, Lehikoinen $\mathrm{P}$, et al. Reduced myocardial carbon-11 hydroxyephedrine retention is associated with poor prognosis in chronic heart failure. Eur J Nucl Med. (2001) 28:373-6. doi: 10.1007/s002590000449

36. Merlet P, Delforge J, Syrota A, Angevin E, Mazière B, Crouzel C, et al. Positron emission tomography with 11C CGP-12177 to assess beta-adrenergic receptor concentration in idiopathic dilated cardiomyopathy. Circulation. (1993) 87:1169-78. doi: 10.1161/01.CIR.87.4. 1169

37. de Jong RM, Willemsen AT, Slart RH, Blanksma PK, van Waarde A, Cornel JH, et al. Myocardial beta-adrenoceptor downregulation in idiopathic dilated cardiomyopathy measured in vivo with PET using the new radioligand (S)-[11C]CGP12388. Eur J Nucl Med Mol Imag. (2005) 32:4437. doi: $10.1007 / \mathrm{s} 00259-004-1701-\mathrm{z}$

38. Yu M, Bozek J, Lamoy M, Guaraldi M, Silva $P$, Kagan $M$, et al. Evaluation of LMI1195, a novel F-18-labeled cardiac neuronal PET imaging agent, in cells and animal models. Circ Cardiovasc Imag. (2011) 4:43543. doi: 10.1161/CIRCIMAGING.110.962126

39. Le Guludec D, Cohen-Solal A, Delforge J, Delahaye N, Syrota A, Merlet P. Increased myocardial muscarinic receptor density in idiopathic dilated cardiomyopathy: an in vivo PET study. Circulation. (1997) 96:3416-22. doi: 10.1161/01.CIR.96. 10.3416

40. Saint-Georges Z, Zayed VK, Dinelle K, Cassidy C, Soucy JP, Massarweh G, et al. First-in-human imaging and kinetic analysis of vesicular acetylcholine transporter density in the heart using [(18)F]FEOBV PET. J Nucl Cardiol. (2021) 28:50-4. doi: 10.1007/s12350-020-02323-w

41. Jenkins WSA, Vesey AT, Stirrat C, Connell M, Lucatelli C, Neale A, et al. Cardiac alpha(V)beta(3) integrin expression following acute myocardial infarction in humans. Heart. (2017) 103:607-15. doi: 10.1136/heartjnl-2016-310115
42. Laitinen I, Notni J, Pohle K, Rudelius M, Farrell E, Nekolla SG, et al. Comparison of cyclic RGD peptides for alphavbeta3 integrin detection in a rat model of myocardial infarction. EJNMMI Res. (2013) 3:38. doi: 10.1186/2191-219X-3-38

43. Orbay H, Zhang Y, Valdovinos HF, Song G, Hernandez R, Theuer CP, et al. Positron emission tomography imaging of CD105 expression in a rat myocardial infarction model with (64)Cu-NOTA-TRC105. Am J Nucl Med Mol Imag. (2013) 4:1-9. Available online at: http://www.ajnmmi.us/files/ ajnmmi1310005.pdf

44. Varasteh Z, Mohanta S, Robu S, Braeuer M, Li Y, Omidvari N, et al. Molecular imaging of fibroblast activity after myocardial infarction using a (68) Galabeled fibroblast activation protein inhibitor, FAPI-04. J Nucl Med. (2019) 60:1743-9. doi: 10.2967/jnumed.119.226993

45. Majmudar MD, Keliher EJ, Heidt T, Leuschner F, Truelove J, Sena $\mathrm{BF}$, et al. Monocyte-directed RNAi targeting CCR2 improves infarct healing in atherosclerosis-prone mice. Circulation. (2013) 127:203846. doi: 10.1161/CIRCULATIONAHA.112.000116

46. Balogh V, Spath N, Alcaide-Corral C, Walton T, Lennen R, Jansen M, et al. Assessment of myocardial fibrosis activity using F-18-fluoroproline positron emission tomography (Pet) in rat models of cardiovascular disease. Heart. (2020) 106:A11-A. doi: 10.1136/heartjnl-2020-SCF.26

47. Fukushima K, Bravo PE, Higuchi T, Schuleri KH, Lin X, Abraham MR, et al. Molecular hybrid positron emission tomography/computed tomography imaging of cardiac angiotensin II type 1 receptors. J Am Coll Cardiol. (2012) 60:2527-34. doi: 10.1016/j.jacc.2012.09.023

48. Vasudevan P, Gaebel R, Doering P, Mueller P, Lemcke H, Stenzel J, et al. 18F-FDG PET-based imaging of myocardial inflammation predicts a functional outcome following transplantation of mESC-derived cardiac induced cells in a mouse model of myocardial infarction. Cells. (2019) 8:1613. doi: $10.3390 /$ cells 8121613

49. Kim GR, Paeng JC, Jung JH, Moon BS, Lopalco A, Denora N, et al. Assessment of TSPO in a rat experimental autoimmune myocarditis model: a comparison study between [(18)F]Fluoromethyl-PBR28 and [(18)F]CB251. Int J Mol Sci. (2018) 19:276. doi: 10.3390/ijms19010276

50. Thackeray JT, Derlin T, Haghikia A, Napp LC, Wang Y, Ross TL, et al. Molecular imaging of the chemokine receptor CXCR4 after acute myocardial infarction. JACC Cardiovasc Imag. (2015) 8:141726. doi: 10.1016/j.jcmg.2015.09.008

51. Thackeray JT, Bankstahl JP, Wang Y, Wollert KC, Bengel FM. Targeting amino acid metabolism for molecular imaging of inflammation early after myocardial infarction. Theranostics. (2016) 6:1768-79. doi: 10.7150/thno.15929

52. Thackeray JT, Hupe HC, Wang Y, Bankstahl JP, Berding G, Ross TL, et al. Myocardial inflammation predicts remodeling and neuroinflammation after myocardial infarction. J Am Coll Cardiol. (2018) 71:263-75. doi: 10.1016/j.jacc.2017.11.024

53. MacAskill MG, Stadulyte A, Williams L, Morgan TEF, Sloan NL, AlcaideCorral CJ, et al. Quantification of macrophage-driven inflammation during myocardial infarction with (18)F-LW223, a novel TSPO radiotracer with binding independent of the rs6971 human polymorphism. J Nucl Med. (2021) 62:536-44. doi: 10.2967/jnumed.120.243600

54. Ponikowski P, Voors AA, Anker SD, Bueno H, Cleland JGF, Coats AJS, et al. 2016 ESC Guidelines for the diagnosis treatment of acute chronic heart failure: the task force for the diagnosis treatment of acute chronic heart failure of the European society of cardiology (ESC) developed with the special contribution of the heart failure association (HFA) of the ESC. Eur Heart J. (2016) 37:2129-200. doi: 10.1093/eurheartj/ehw128

55. Bax JJ, Delgado V. Myocardial viability as integral part of the diagnostic and therapeutic approach to ischemic heart failure. J Nucl Cardiol. (2015) 22:229-45. doi: 10.1007/s12350-015-0096-5

56. Dorans KS, Mills KT, Liu Y, He J. Trends in prevalence and control of hypertension according to the 2017 American college of cardiology/American heart association (ACC/AHA) guideline. J Am Heart Assoc. (2018) 7:e008888. doi: 10.1161/JAHA.118.008888

57. Hendel RC, Berman DS, Di Carli MF, Heidenreich PA, Henkin RE, Pellikka PA, et al. ACCF/ASNC/ACR/AHA/ASE/SCCT/SCMR/SNM 2009 appropriate use criteria for cardiac radionuclide imaging: a report of the American college of cardiology foundation appropriate use criteria 
task force, the American society of nuclear cardiology, the American college of radiology, the American heart association, the American society of echocardiography, the society of cardiovascular computed tomography, the society for cardiovascular magnetic resonance, and the society of nuclear medicine. J Am Coll Cardiol. (2009) 53:220129. doi: 10.1016/j.jacc.2009.02.013

58. Angelidis G, Giamouzis G, Karagiannis G, Butler J, Tsougos I, Valotassiou V, et al. SPECT and PET in ischemic heart failure. Heart Fail Rev. (2017) 22:243-61. doi: 10.1007/s10741-017-9594-7

59. Hesse B, Tagil K, Cuocolo A, Anagnostopoulos C, Bardies M, Bax J, et al. EANM/ESC procedural guidelines for myocardial perfusion imaging in nuclear cardiology. Eur J Nucl Med Mol Imag. (2005) 32:85597. doi: 10.1007/s00259-005-1779-y

60. Melero-Ferrer JL, Lopez-Vilella R, Morillas-Climent H, Sanz-Sanchez J, Sanchez-Lazaro IJ, Almenar-Bonet L, et al. Novel imaging techniques for heart failure. Card Fail Rev. (2016) 2:27-34. doi: 10.15420/cfr.2015:29:2

61. Schinkel AF, Bax JJ, Poldermans D, Elhendy A, Ferrari R, Rahimtoola SH. Hibernating myocardium: diagnosis and patient outcomes. Curr Probl Cardiol. (2007) 32:375-410. doi: 10.1016/j.cpcardiol.2007.04.001

62. Li X, Rosenkrans ZT, Wang J, Cai W. PET imaging of macrophages in cardiovascular diseases. Am J Transl Res. (2020) 12:1491-514.

63. Pelletier-Galarneau M, Ruddy TD. Molecular imaging of coronary inflammation. Trends Cardiovasc Med. (2019) 29:1917. doi: 10.1016/j.tcm.2018.08.004

64. Wells RG, Ruddy TD. The dream of imaging coronary artery inflammation with FDG PET/CT imaging. J Nucl Cardiol. (2017) 24:1171-4. doi: 10.1007/s12350-016-0549-5

65. McArdle B, Dowsley TF, Cocker MS, Ohira H, deKemp RA, DaSilva J, et al. Cardiac PET: metabolic and functional imaging of the myocardium. Semin Nucl Med. (2013) 43:434-48. doi: 10.1053/j.semnuclmed.2013.06.001

66. Tarkin JM, Joshi FR, Rudd JHF. PET imaging of inflammation in atherosclerosis. Nat Rev Cardiol. (2014) 11:44357. doi: $10.1038 /$ nrcardio. 2014.80

67. Nishida K, Otsu K. Cell death in heart failure. Circ J. (2008) 72 (Suppl. A):A17-21. doi: 10.1253/circj.CJ-08-0669

68. Moe GW, Marín-García J. Role of cell death in the progression of heart failure. Heart Fail Rev. (2016) 21:157-67. doi: 10.1007/s10741-016-9532-0

69. Yao S, Hu K, Tang G, Gao S, Tang C, Yao B, et al. Molecular PET imaging of cyclophosphamide induced apoptosis with $<$ sup $>18</$ sup $>$ F-ML- 8 . Biomed Res Int. (2015) 2015:317403. doi: 10.1155/2015/317403

70. Packer M. The neurohormonal hypothesis: a theory to explain the mechanism of disease progression in heart failure. J Am Coll Cardiol. (1992) 20:248-54. doi: 10.1016/0735-1097(92)90167-L

71. Olshansky B, Sabbah HN, Hauptman PJ, Colucci WS. Parasympathetic nervous system and heart failure. Circulation. (2008) 118:86371. doi: 10.1161/CIRCULATIONAHA.107.760405

72. Law MP, Schafers K, Kopka K, Wagner S, Schober O, Schafers M. Molecular imaging of cardiac sympathetic innervation by $11 \mathrm{C}$ mHED and PET: from man to mouse? J Nucl Med. (2010) 51:126976. doi: 10.2967/jnumed.110.074997

73. Yu M, Bozek J, Lamoy M, Kagan M, Benites P, Onthank D, et al. LMI1195 PET imaging in evaluation of regional cardiac sympathetic denervation and its potential role in antiarrhythmic drug treatment. Eur J Nucl Med Mol I. (2012) 39:1910-9. doi: 10.1007/s00259-012-2204-y

74. Mu L, Kramer SD, Warnock GI, Haider A, Bengs S, Cartolano G, et al. [(11)C]mHED PET follows a two-tissue compartment model in mouse myocardium with norepinephrine transporter (NET)-dependent uptake, while [(18)F]LMI1195 uptake is NET-independent. EJNMMI Res. (2020) 10:114. doi: 10.1186/s13550-020-00700-7

75. Syrota A, Comar D, Paillotin G, Davy JM, Aumont MC, Stulzaft O, et al. Muscarinic cholinergic receptor in the human heart evidenced under physiological conditions by positron emission tomography. Proc Natl Acad Sci USA. (1985) 82:584-8. doi: 10.1073/pnas.82.2.584

76. DeGrado TR, Mulholland GK, Wieland DM, Schwaiger M. Evaluation of (-)[18F]fluoroethoxybenzovesamicol as a new PET tracer of cholinergic neurons of the heart. Nucl Med Biol. (1994) 21:189-95. doi: 10.1016/0969-8051(94)90008-6
77. Lara A, Damasceno DD, Pires R, Gros R, Gomes ER, Gavioli M, et al. Dysautonomia due to reduced cholinergic neurotransmission causes cardiac remodeling and heart failure. Mol Cell Biol. (2010) 30:174656. doi: 10.1128/MCB.00996-09

78. Tsukamoto T, Morita K, Naya M, Inubushi M, Katoh C, Nishijima K, et al. Decreased myocardial beta-adrenergic receptor density in relation to increased sympathetic tone in patients with nonischemic cardiomyopathy. $J$ Nucl Med. (2007) 48:1777-82. doi: 10.2967/jnumed.107.043794

79. Chen X, Hirano M, Werner RA, Decker M, Higuchi T. Novel 18F-Labeled PET imaging agent FV45 targeting the renin-angiotensin system. ACS Omega. (2018) 3:10460-70. doi: 10.1021/acsomega.8b01885

80. Dilsizian V, Zynda TK, Petrov A, Ohshima S, Tahara N, Haider N, et al. Molecular imaging of human ACE-1 expression in transgenic rats. JACC Cardiovasc Imaging. (2012) 5:409-18. doi: 10.1016/j.jcmg.2011.10.008

81. Talman V, Ruskoaho H. Cardiac fibrosis in myocardial infarction-from repair and remodeling to regeneration. Cell Tissue Res. (2016) 365:56381. doi: 10.1007/s00441-016-2431-9

82. Weber KT, Brilla CG. Pathological hypertrophy and cardiac interstitium - fibrosis and renin-angiotensin-aldosterone system. Circulation. (1991) 83:1849-65. doi: 10.1161/01.CIR.83.6.1849

83. Ohta K, Kim SK, Wanibuchi H, Ganten D, Iwao H. Contribution of local renin-angiotensin system to cardiac hypertrophy, phenotypic modulation, and remodeling in TGR(mRen2)27 transgenic rats. Circulation. (1996) 94:785-91. doi: 10.1161/01.CIR.94.4.785

84. Schnee JM, Hsueh WA. Angiotensin II, adhesion, and cardiac fibrosis. Cardiovasc Res. (2000) 46:264-8. doi: 10.1016/S0008-6363(00)00044-4

85. Montesi SB, Desogere P, Fuchs BC, Caravan P. Molecular imaging of fibrosis: recent advances and future directions. J Clin Invest. (2019) 129:2433. doi: 10.1172/JCI122132

86. Giesel FL, Kratochwil C, Lindner T, Marschalek MM, Loktev A, Lehnert $\mathrm{W}$, et al. 68Ga-FAPI PET/CT: biodistribution and preliminary dosimetry estimate of 2 DOTA-containing FAP-targeting agents in patients with various cancers. J Nucl Med. (2019) 60:386-92. doi: 10.2967/jnumed.118. 215913

87. Conroy KP, Kitto LJ, Henderson NC. av integrins: key regulators of tissue fibrosis. Cell and Tissue Res. (2016) 365:511-9. doi: 10.1007/s00441-016-2407-9

88. Henderson NC, Sheppard D. Integrin-mediated regulation of TGFbeta in fibrosis. Biochim Biophys Acta. (2013) 1832:8916. doi: 10.1016/j.bbadis.2012.10.005

89. Sheppard D. Epithelial-mesenchymal interactions in fibrosis and repair. Transforming growth factor-beta activation by epithelial cells and fibroblasts. Ann Am Thorac Soc. (2015) 12(Suppl. 1):S21-3. doi: 10.1513/AnnalsATS.201406-245MG

90. Breuss JM, Gallo J, DeLisser HM, Klimanskaya IV, Folkesson HG, Pittet JF, et al. Expression of the beta 6 integrin subunit in development, neoplasia and tissue repair suggests a role in epithelial remodeling. J Cell Sci. (1995) 108 (Pt 6):2241-51. doi: $10.1242 /$ jcs.108.6.2241

91. Berk BC, Fujiwara K, Lehoux S. ECM remodeling in hypertensive heart disease. J Clin Invest. (2007) 117:568-75. doi: 10.1172/JCI31044

92. Fischer CR, Müller A, Bochsler B, Rancic Z, Kaufmann P, Schibli R, et al. Assessment of an elastin binding molecule for PET imaging of atherosclerotic plaques. Am J Nucl Med Mol Imag. (2013) 3:326-35.

93. Geisler S, Ermert J, Stoffels G, Willuweit A, Galldiks N, Filss CP, et al. Isomers of 4-[18F]fluoro-proline: radiosynthesis, biological evaluation and results in humans using PET. Curr Radiopharm. (2014) 7:12332. doi: $10.2174 / 1874471007666140902152916$

94. Wester HJ, Herz M, Senekowitsch-Schmidtke R, Schwaiger M, Stocklin G, Hamacher K. Preclinical evaluation of 4-[18F]fluoroprolines: diastereomeric effect on metabolism and uptake in mice. Nucl Med Biol. (1999) 26:25965. doi: 10.1016/S0969-8051(98)00107-3

95. Barbul A. Proline precursors to sustain mammalian collagen synthesis. $J$ Nutr. (2008) 138:2021S-4S. doi: 10.1093/jn/138.10.2021S

96. Windisch P, Zwahlen DR, Koerber SA, Giesel FL, Debus J, Haberkorn U, et al. Clinical results of fibroblast activation protein (FAP) specific PET and implications for radiotherapy planning: systematic review. Cancers. (2020) 12:2629. doi: $10.3390 /$ cancers 12092629 
97. Guglielmo P, Guerra L. Radiolabeled fibroblast activation protein inhibitor (FAPI) PET in oncology: has the time come for 18F-fluorodeoxyglucose to think to a well-deserved retirement? Clin Transl Imag. (2021) 9:12. doi: 10.1007/s40336-020-00402-z

98. Humeres C, Frangogiannis NG. Fibroblasts in the infarcted, remodeling, and failing heart. JACC Basic Transl Sci. (2019) 4:449-67. doi: 10.1016/j.jacbts.2019.02.006

99. Wallace WE, Gupta NC, Hubbs AF, Mazza SM, Bishop HA, Keane MJ, et al. Cis-4-[18F]Fluoro-l-Proline PET imaging of pulmonary fibrosis in a rabbit model. J Nucl Med. (2002) 43:413-20. Available online at: https://jnm. snmjournals.org/content/jnumed/43/3/413.full.pdf

100. Suthahar N, Meijers WC, Sillje HHW, de Boer RA. From inflammation to fibrosis-molecular and cellular mechanisms of myocardial tissue remodelling and perspectives on differential treatment opportunities. Curr Heart Fail Rep. (2017) 14:235-50. doi: 10.1007/s11897-017-0343-y

101. Lee SB, Kalluri R. Mechanistic connection between inflammation and fibrosis. Kidney Int. (2010) 78:S22-6. doi: 10.1038/ki.2010.418

102. Serhan CN, Brain SD, Buckley CD, Gilroy DW, Haslett C, O’Neill LAJ, et al. Resolution of inflammation: state of the art, definitions and terms. Faseb J. (2007) 21:325-32. doi: 10.1096/fj.06-7227rev

103. Ueha S, Shand FHW, Matsushima K. Cellular and molecular mechanisms of chronic inflammation-associated organ fibrosis. Front Immunol. (2012) 3:71. doi: 10.3389/fimmu.2012.00071

104. Yndestad A, Damas JK, Oie E, Ueland T, Gullestad L, Aukrust P. Systemic inflammation in heart failure - the whys and wherefores. Heart Fail Rev. (2006) 11:83-92. doi: 10.1007/s10741-006-9196-2

105. Schulze PC, Lee RT. Macrophage-mediated cardiac fibrosis. Circ Res. (2004) 95:552-3. doi: 10.1161/01.RES.0000143420.87587.9e

106. Ma F, Li Y, Jia L, Han Y, Cheng J, Li H, et al. Macrophage-stimulated cardiac fibroblast production of IL-6 is essential for TGF beta/Smad activation and cardiac fibrosis induced by angiotensin II. PLoS ONE. (2012) 7:e35144. doi: 10.1371/journal.pone.0035144

107. Sopel MJ, Rosin NL, Falkenham AG, Bezuhly M, Esmon CT, Lee TD, et al. Treatment with activated protein $\mathrm{C}(\mathrm{aPC})$ is protective during the development of myocardial fibrosis: an angiotensin II infusion model in mice. PLoS ONE. (2012) 7:e45663. doi: 10.1371/journal.pone.0045663

108. Epelman S, Lavine KJ, Beaudin AE, Sojka DK, Carrero JA, Calderon B, et al. Embryonic and adult-derived resident cardiac macrophages are maintained through distinct mechanisms at steady state and during inflammation. Immunity. (2014) 40:91-104. doi: 10.1016/j.immuni.2013.11.019

109. Newby AC. Metalloproteinase expression in monocytes and macrophages and its relationship to atherosclerotic plaque instability. Arterioscl Throm Vas. (2008) 28:2108-U20. doi: 10.1161/ATVBAHA.108.173898

110. Moore L, Fan D, Basu R, Kandalam V, Kassiri Z. Tissue inhibitor of metalloproteinases (TIMPs) in heart failure. Heart Fail Rev. (2012) 17:693706. doi: 10.1007/s10741-011-9266-y

111. Madsen DH, Leonard D, Masedunskas A, Moyer A, Jurgensen HJ, Peters $\mathrm{DE}$, et al. M2-like macrophages are responsible for collagen degradation through a mannose receptor-mediated pathway. J Cell Biol. (2013) 202:95166. doi: $10.1083 /$ jcb. 201301081

112. Falkenham A, de Antueno R, Rosin N, Betsch D, Lee TD, Duncan R, et al. Nonclassical resident macrophages are important determinants in the development of myocardial fibrosis. Am J Pathol. (2015) 185:92742. doi: 10.1016/j.ajpath.2014.11.027

113. Bird J, Izquierdo-Garcia D, Davies J, Rudd J, Probst K, Figg N, et al. Evaluation of translocator protein quantification as a tool for characterising macrophage burden in human carotid atherosclerosis. Atherosclerosis. (2010) 210:388-91. doi: 10.1016/j.atherosclerosis.2009.11.047

114. Rischpler C, Dirschinger RJ, Nekolla SG, Kossmann H, Nicolosi S, Hanus F, et al. Prospective evaluation of 18F-fluorodeoxyglucose uptake in postischemic myocardium by simultaneous positron emission tomography/magnetic resonance imaging as a prognostic marker of functional outcome. Circ Cardiovasc Imag. (2016) 9:e004316. doi: 10.1161/CIRCIMAGING.115.004316

115. Glaudemans AWJM, Enting RH, Heesters MAAM, Dierckx RAJO, van Rheenen RWJ, Walenkamp AME, et al. Value of 11C-methionine PET in imaging brain tumours and metastases. Eur J Nucl Med Mol I. (2013) 40:615-35. doi: 10.1007/s00259-012-2295-5
116. Tarkin JM, Joshi FR, Evans NR, Chowdhury MM, Figg NL, Shah AV, et al. Detection of atherosclerotic inflammation by (68)Ga-DOTATATE PET compared to [(18)F]FDG PET imaging. J Am Coll Cardiol. (2017) 69:1774-91. doi: 10.1016/j.jacc.2017.01.060

117. Gormsen LC, Haraldsen A, Kramer S, Dias AH, Kim WY, Borghammer P. A dual tracer (68)Ga-DOTANOC PET/CT and (18)F-FDG PET/CT pilot study for detection of cardiac sarcoidosis. EJNMMI Res. (2016) 6:52. doi: 10.1186/s13550-016-0207-6

118. Heo GS, Kopecky B, Sultan D, Ou M, Feng G, Bajpai G, et al. Molecular imaging visualizes recruitment of inflammatory monocytes and macrophages to the injured heart. Circ Res. (2019) 124:88190. doi: 10.1161/CIRCRESAHA.118.314030

119. Heo GS, Bajpai G, Li W, Luehmann HP, Sultan DH, Dun H, et al. Targeted PET imaging of chemokine receptor 2-positive monocytes and macrophages in the injured heart. J Nucl Med. (2021) 62:1114. doi: 10.2967/jnumed.120.244673

120. Tahara N, Mukherjee J, de Haas HJ, Petrov AD, Tawakol A, Haider N, et al. 2deoxy-2-[18F]fluoro-d-mannose positron emission tomography imaging in atherosclerosis. Nat Med. (2014) 20:215-9. doi: 10.1038/nm.3437

121. Zavala F, Haumont J, Lenfant M. Interaction of benzodiazepines with mouse macrophages. Eur J Pharmacol. (1984) 106:5616. doi: 10.1016/0014-2999(84)90059-1

122. Morin D, Musman J, Pons S, Berdeaux A, Ghaleh B. Mitochondrial translocator protein (TSPO): from physiology to cardioprotection. Biochem Pharmacol. (2016) 105:1-13. doi: 10.1016/j.bcp.2015.12.003

123. Honold L, Nahrendorf M. Resident and monocyte-derived macrophages in cardiovascular disease. Circ Res. (2018) 122:11327. doi: 10.1161/CIRCRESAHA.117.311071

124. Thackeray J, Ross TL, Bankstahl J, Wester H, Bengel F. Targeting cardiovascular inflammation for imaging: comparison of the uptake of multiple tracers in leukocyte subpopulations. J Nucl Med. (2017) 58(Suppl. 1):302. Available online at: https://jnm.snmjournals.org/content/ 58/supplement_1/302

125. Banati RB. Visualising microglial activation in vivo. Glia. (2002) 40:20617. doi: $10.1002 /$ glia. 10144

126. Chauveau F, Boutin H, Van Camp N, Dolle F, Tavitian B. Nuclear imaging of neuroinflammation: a comprehensive review of [C-11]PK11195 challengers. Eur J Nucl Med Mol I. (2008) 35:2304-19. doi: 10.1007/s00259-008-0908-9

127. Venneti S, Wang G, Wiley CA. The high affinity peripheral benzodiazepine receptor ligand DAA1106 binds to activated and infected brain macrophages in areas of synaptic degeneration: implications for PET imaging of neuroinflammation in lentiviral encephalitis. Neurobiol Dis. (2008) 29:23241. doi: 10.1016/j.nbd.2007.08.016

128. Boutin H, Chauveau F, Thominiaux C, Gregoire MC, James ML, Trebossen $\mathrm{R}$, et al. C-11-DPA-713: A novel peripheral benzodiazepine receptor PET ligand for in vivo imaging of neuroinflammation. J Nucl Med. (2007) 48:57381. doi: 10.2967/jnumed.106.036764

129. Venneti S, Wagner AK, Wang G, Slagel SL, Chen X, Lopresti BJ, et al. The high affinity peripheral benzodiazepine receptor ligand DAA1106 binds specifically to microglia in a rat model of traumatic brain injury: implications for PET imaging. Exp Neurol. (2007) 207:11827. doi: 10.1016/j.expneurol.2007.06.003

130. Owen DR, Yeo AJ, Gunn RN, Song K, Wadsworth G, Lewis A, et al. An $18-\mathrm{kDa}$ translocator protein (TSPO) polymorphism explains differences in binding affinity of the PET radioligand PBR28. J Cerebr Blood F Met. (2012) 32:1-5. doi: 10.1038/jcbfm.2011.147

131. Tiwari AK, Ji B, Yui J, Fujinaga M, Yamasaki T, Xie L, et al. [18F]FEBMP: positron emission tomography imaging of tspo in a model of neuroinflammation in rats, and in vitro autoradiograms of the human brain. Theranostics. (2015) 5:961-9. doi: 10.7150/thno.12027

132. Berroteran-Infante N, Kalina T, Fetty L, Janisch V, Velasco $\mathrm{R}$, Vraka C, et al. (R)-[(18)F]NEBIFQUINIDE: a promising new PET tracer for TSPO imaging. Eur J Med Chem. (2019) 176:410-8. doi: 10.1016/j.ejmech.2019.05.008

133. Qiao L, Fisher E, McMurray L, Milicevic Sephton S, Hird M, KuzhuppillyRamakrishnan $\mathrm{N}$, et al. Radiosynthesis of (R,S)-[(18) F]GE387: a potential PET radiotracer for imaging translocator protein $18 \mathrm{kDa}$ (TSPO) with low binding sensitivity to the human gene polymorphism 
rs6971. Chem Med Chem. (2019) 14:982-93. doi: 10.1002/cmdc.2019 00023

134. Hatori A, Yui J, Xie L, Kumata K, Yamasaki T, Fujinaga M, et al. Utility of translocator protein $(18 \mathrm{kDa})$ as a molecular imaging biomarker to monitor the progression of liver fibrosis. Sci Rep. (2015) 5:17327. doi: $10.1038 /$ srep 17327

135. De Boer RA, Pinto YM, van Veldhuisen DJ. The imbalance between oxygen demand and supply as a potential mechanism in the pathophysiology of heart failure: the role of microvascular growth and abnormalities. Microcirculation. (2003) 10:113-26. doi: 10.1080/713773607

136. Marcus ML, Koyanagi S, Harrison DG, Doty DB, Hiratzka LF, Eastham CL. Abnormalities in the coronary circulation that occur as a consequence of cardiac-hypertrophy. Am J Med. (1983) 75(3a):62-6. doi: 10.1016/0002-9343(83)90120-1

137. Tomanek RJ. Response of the coronary vasculature to myocardial hypertrophy. J Am Coll Cardiol. (1990) 15:52833. doi: 10.1016/0735-1097(90)90620-5

138. Sano M, Minamino T, Toko H, Miyauchi H, Orimo M, Qin YJ, et al. p53-induced inhibition of Hif-1 causes cardiac dysfunction during pressure overload. Nature. (2007) 446:444-8. doi: 10.1038/nature05602

139. Friehs I, Margossian RE, Moran AM, Cao-Danh H, Moses MA, del Nido PJ. Vascular endothelial growth factor delays onset of failure in pressure-overload hypertrophy through matrix metalloproteinase activation and angiogenesis. Basic Res Cardiol. (2006) 101:204-13. doi: 10.1007/s00395-005-0581-0

140. Carmeliet P, Jain RK. Angiogenesis in cancer and other diseases. Nature. (2000) 407:249-57. doi: 10.1038/35025220

141. Angelo LS, Kurzrock R. Vascular endothelial growth factor and its relationship to inflammatory mediators. Clin Cancer Res. (2007) 13:282530. doi: 10.1158/1078-0432.CCR-06-2416

142. Saraste A, Knuuti J. PET imaging in heart failure: the role of new tracers. Heart Fail Rev. (2017) 22:501-11. doi: 10.1007/s10741-017-9620-9

143. Meoli DF, Sadeghi MM, Krassilnikova S, Bourke BN, Giordano FJ, Dione DP, et al. Noninvasive imaging of myocardial angiogenesis following experimental myocardial infarction. J Clin Invest. (2004) 113:168491. doi: 10.1172/JCI200420352

144. Sun M, Opavsky MA, Stewart DJ, Rabinovitch M, Dawood F, Wen WH, et al. Temporal response and localization of integrins betal and beta 3 in the heart after myocardial infarction: regulation by cytokines. Circulation. (2003) 107:1046-52. doi: 10.1161/01.CIR.0000051363.86009.3C

145. van den Borne SW, Isobe S, Verjans JW, Petrov A, Lovhaug D, Li $\mathrm{P}$, et al. Molecular imaging of interstitial alterations in remodeling myocardium after myocardial infarction. J Am Coll Cardiol. (2008) 52:201728. doi: 10.1016/j.jacc.2008.07.067

146. Mandic L, Traxler D, Gugerell A, Zlabinger K, Lukovic D, Pavo N, et al. Molecular imaging of angiogenesis in cardiac regeneration. Curr Cardiovasc Imag Rep. (2016) 9:27. doi: 10.1007/s12410-016-9389-6

147. Horton MA. The alpha v beta 3 integrin "vitronectin receptor". Int J Biochem Cell Biol. (1997) 29:721-5. doi: 10.1016/S1357-2725(96)00155-0

148. Higuchi T, Bengel FM, Seidl S, Watzlowik P, Kessler H, Hegenloh R, et al. Assessment of alphavbeta3 integrin expression after myocardial infarction by positron emission tomography. Cardiovasc Res. (2008) 78:395403. doi: 10.1093/cvr/cvn033

149. Atkinson SJ, Ellison TS, Steri V, Gould E, Robinson SD. Redefining the role(s) of endothelial alphavbeta3-integrin in angiogenesis. Biochem Soc Trans. (2014) 42:1590-5. doi: 10.1042/BST20140206

150. Rodriguez-Porcel M, Cai WB, Gheysens O, Willmann JK, Chen K, Wang H, et al. Imaging of VEGF receptor in a rat myocardial infarction model using PET. J Nucl Med. (2008) 49:667-73. doi: 10.2967/jnumed.107.040576
151. Gao H, Lang L, Guo N, Cao F, Quan Q, Hu S, et al. PET imaging of angiogenesis after myocardial infarction/reperfusion using a one-step labeled integrin-targeted tracer 18F-AlF-NOTA-PRGD2. Eur J Nucl Med Mol Imag. (2012) 39:683-92. doi: 10.1007/s00259-0112052-1

152. Sun Y, Zeng Y, Zhu Y, Feng F, Xu W, Wu C, et al. Application of (68)GaPRGD2 PET/CT for alphavbeta3-integrin imaging of myocardial infarction and stroke. Theranostics. (2014) 4:778-86. doi: 10.7150/thno.8809

153. Eo JS, Paeng JC, Lee S, Lee YS, Jeong JM, Kang KW, et al. Angiogenesis imaging in myocardial infarction using 68Ga-NOTA-RGD PET: characterization and application to therapeutic efficacy monitoring in rats. Coron Artery Dis. (2013) 24:303-11. doi: 10.1097/MCA.0b013e3283608c32

154. Stacy MR, Paeng JC, Sinusas AJ. The role of molecular imaging in the evaluation of myocardial and peripheral angiogenesis. Ann Nucl Med. (2015) 29:217-23. doi: 10.1007/s12149-015-0961-y

155. Ni M, Yang ZW, Li DJ, Li Q, Zhang SH, Su DF, et al. A potential role of alpha-7 nicotinic acetylcholine receptor in cardiac angiogenesis in a pressure-overload rat model. J Pharmacol Sci. (2010) 114:3119. doi: 10.1254/jphs.09335FP

156. Heeschen C, Jang JJ, Weis M, Pathak A, Kaji S, Hu RS, et al. Nicotine stimulates angiogenesis and promotes tumor growth and atherosclerosis. Nat Med. (2001) 7:833-9. doi: 10.1038/89961

157. Heeschen C, Weis M, Aicher A, Dimmeler S, Cooke JP. A novel angiogenic pathway mediated by non-neuronal nicotinic acetylcholine receptors. J Clin Invest. (2002) 110:527-36. doi: 10.1172/JCI021 4676

158. Boswijk E, Bauwens M, Mottaghy FM, Wildberger JE, Bucerius J. Potential of alpha7 nicotinic acetylcholine receptor PET imaging in atherosclerosis. Methods. (2017) 130:90-104. doi: 10.1016/j.ymeth.2017. 06.008

159. Wong DF, Kuwabara H, Pomper M, Holt DP, Brasic JR, George N, et al. Human brain imaging of alpha $7 \mathrm{nAChR}$ with [F-18]ASEM: a new PET radiotracer for neuropsychiatry and determination of drug occupancy. Mol Imaging Biol. (2014) 16:730-8. doi: 10.1007/s11307-014-0 $779-3$

160. Bucerius J, Rotering S, Deuther-Conrad W, Donat C, Fischer S, Xiong $\mathrm{GM}$, et al. $\left[{ }^{18} \mathrm{~F}\right] \mathrm{NS} 14490$ - A novel PET tracer for in vivo imaging of $\alpha 7$ nicotinic acetylcholine receptors $(\alpha 7 \mathrm{nAChR})$ in brain vasculature $J$ Nucl Med. (2014) 55 (supplement 1):1695. Available online at: https://jnm. snmjournals.org/content/55/supplement_1/1695

Conflict of Interest: The authors declare that the research was conducted in the absence of any commercial or financial relationships that could be construed as a potential conflict of interest.

Publisher's Note: All claims expressed in this article are solely those of the authors and do not necessarily represent those of their affiliated organizations, or those of the publisher, the editors and the reviewers. Any product that may be evaluated in this article, or claim that may be made by its manufacturer, is not guaranteed or endorsed by the publisher.

Copyright (c) 2021 Balogh, MacAskill, Hadoke, Gray and Tavares. This is an openaccess article distributed under the terms of the Creative Commons Attribution License (CC BY). The use, distribution or reproduction in other forums is permitted, provided the original author(s) and the copyright owner(s) are credited and that the original publication in this journal is cited, in accordance with accepted academic practice. No use, distribution or reproduction is permitted which does not comply with these terms. 